\title{
Osseointegration of Hydroxyapatite Implants in Rat Tibial Defects with Sciatic Nerve Injury
}

\author{
Oseointegración de Implantes de Hidroxiapatita en Defectos \\ Tibiales de Ratas con Lesión del Nervio Ciático
}

\author{
Marcelo Rodrigues da Cunha*; Isabela Ortiz Laraia*; Guacira R. Franco*; Natalia N. Miguel*; \\ Ana A. Maciel*; Geovane Ribeiro dos Santos* \& Ricardo Noboro Isayama**
}

DA CUNHA, M. R.; LARAIA, I. O.; FRANCO, G. R.; MIGUEL, N. N.; MACIEL, A. A.; DOS SANTOS, G. R. \& ISAYAMA, R. N. Osseointegration of hydroxyapatite implants in rat tibial defects with sciatic nerve injury. Int. J. Morphol., 33(2):620-625, 2015.

SUMMARY: Bone metabolism is influenced by different factors and muscle activity acts as a stimulator of bone plasticity. Conditions such as nerve injuries can compromise bone physiology due to muscle inactivity. Preview studies have shown that nerve damage reduces $\mathrm{P}$ substance and calcitonin gene-related peptides, also known as neuropeptides that may have a key role on bone healing. Therefore, this study evaluated the osseointegration of hydroxyapatite implants in tibial defects of rats submitted to unilateral sciatic nerve section. Twelve Wistar rats were divided into two groups (G1 and G2). In G1, the sciatic nerve was left intact and in G2 the left sciatic nerve was completely sectioned. An experimental tibial bone defect was then created in both groups and filled with hydroxyapatite granules. The animals were sacrificed 2 months after implantation and samples were submitted to macroscopic inspection and histological analysis. Good radiopacity of the hydroxyapatite granules and radiographic definition of the bone defect were noted. Histologic analysis revealed formation of new bone adjacent to the hydroxyapatite granules in G1 and, to a lesser extent, in G2 in which the proliferation of connective tissue predominated at the implant site. The formation of new bone stimulated by hydroxyapatite in bone defects can be expected even in animals with limb paralysis due to nerve injury; however, bone formation occurs at a slower speed in these animals and the volume of newly formed bone is lower.

KEY WORDS: Hydroxyapatite; Sciatic nerve; Bone healing.

\section{INTRODUCTION}

Spinal cord injuries predispose the patient to the occurrence of different diseases, including disuse osteoporosis due to alterations in calcium metabolism (Lee et al., 1997) as a result of impaired function of the neuromuscular system (Wilmet et al., 1995; Kocina, 1997). The lack of weight bearing has serious consequences for the skeleton, altering bone mineral density (Biering-Sorensen et al., 1998; Demulder et al., 1998).

The clinical presentation of osteoporosis in paraplegic patients with peripheral nerve injuries is the result of a disproportional increase in bone resorption due to a lack of balance between the activities of bone cells, leading to an imbalance in bone remodeling (Brito et al., 2002). As a consequence, bones become more fragile and the incidence of bone fractures increases. Fractures accompanied by intense bone mass loss generally require the use of natural grafts such as autologous bone grafts.
Autologous bone grafts are frequently used in many orthopedic procedures when bone loss is extensive. However, the use of these grafts is associated with some disadvantages such as donor site morbidity, limited supply, risk of bacterial contamination and transmission of diseases, as well as nonunion and poor bone quality. In view of these disadvantages, other bone grafts and synthetic substitutes have been tested as alternatives for bone reconstruction (Babiker, 2013).

Synthetic bone substitutes have many advantages over natural autologous grafts, such as easy sterilization, unlimited availability of the amount necessary for bone healing, and easy storage (LeGeros, 2008). An important biomaterial that promotes significant osteoconduction during bone healing is calcium phosphate. This ceramic has been commercialized since the 1970s in the form of hydroxyapatite and tricalcium phosphate and has received

\footnotetext{
* Department of Morphology and Pathology, Faculty of Medicine of Jundiaí (FMJ), São Paulo, Brazil.

** School of Medicine, Federal University of Ouro Preto (UFOP), São Paulo, Brazil.
} 
considerable attention in the fields of plastic, orthopedic, oral-maxillofacial and dental surgery (LeGeros, 2008).

Hydroxyapatite $(\mathrm{Ca} 5(\mathrm{PO} 4) \mathrm{OH})$ is a calcium phosphate ceramic whose composition resembles that of bone mineral. The material is biocompatible and non-toxic, characteristics that render it well accepted by patients. Hydroxyapatite can be produced for clinical use in the form of blocks or granules and as porous or dense material. Some investigators criticize the implantation of the dense type since it does not promote bone growth into the material and of hydroxyapatite blocks since they are difficult to model and because of their fragility when submitted to a mechanical load (Hönig et al., 1998). Porous granules are extensively studied because they facilitate osteoblast infiltration and the proliferation of blood vessels which are essential for the regeneration process, adapt to the contour of the bone defect, are chemically stable, can be produced in unlimited amounts, and do not induce immune rejection in adjacent tissue Porous hydroxyapatite granules therefore represent a good alternative for bone regeneration (Sugata et al., 2011).

However, some factors that compromise bone metabolism, such as hormone deficiency, diabetes (da Cunha et al., 2011), smoking (Franco et al., 2013) and muscle inactivity due to nerve injury, can interfere with the natural fracture healing process. Therefore, the objective of the present study was to evaluate the osteogenic capacity of hydroxyapatite implanted into experimental left tibial defects in rats with complete sectioning of the left sciatic nerve.

\section{MATERIAL AND METHOD}

Animals and study design. Twelve male Wistar rats (Rattus norvegicus), 4 months old and weighing approximately 380 $\mathrm{g}$, were used. The animals were divided into two groups of 6 animals each: group 1 (G1) consisted of animals submitted to the creation of a bone defect in the left tibia implanted with hydroxyapatite granules in which the sciatic nerves were left intact; group 2 (G2) consisted of animals submitted to the creation of a bone defect in the left tibia implanted with hydroxyapatite granules in which the left sciatic nerve was sectioned. The study was approved by the Ethics Committee of the School of Medicine of Jundiaí (Protocol 98/2010).

Surgical Procedures: Complete sectioning of the left sciatic nerve in G2. Animals of G2 were weighed and anesthetized by intramuscular injection of ketamine hydrochloride (Francotar, Sespo Ind. e Com., Jacareí, São Paulo, Brazil) and xylazine hydrochloride (2\% Virbaxyl, Virbac Brasil Ind. e Com., São Paulo, Brazil) at a proportion of $1: 1$ (dose of $0.10 \mathrm{mg} / 100 \mathrm{~g}$ body weight). After anesthesia and sterilization of the surgical field, a skin incision was made in the region of the left gluteus and the skin was elevated to expose the gluteus maximus muscle. After sectioning of this musculature, the left sciatic nerve was exposed and a $0.4 \mathrm{~cm}$ fragment was removed (Fig. 1). Four months after this procedure, the same animals were submitted to another surgery to create a bone defect that was filled with hydroxyapatite granules.

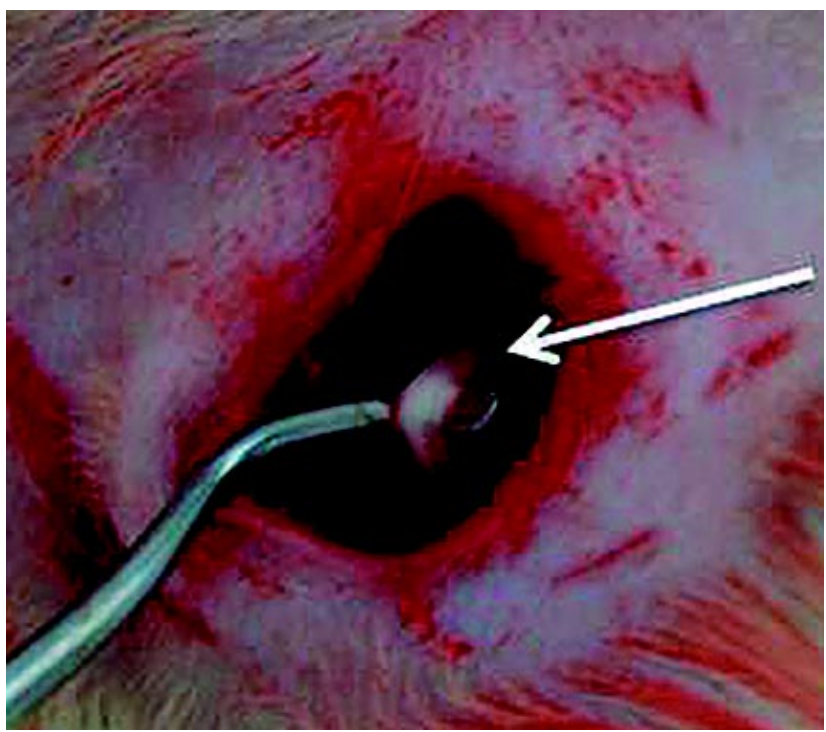

Fig. 1. Sciatic nerve section of the animal.

Bone defect creation. Animals of G1 and G2 were anesthetized as described in the previous item. Next, a skin incision was made in the anterior region of the left limb in order to expose the anterior and proximal surface of the left tibia. A bone defect was drilled in the left tibia with a 3.0 $\mathrm{mm}$ trephine drill coupled to the pen of a mini-motor until the medullary canal was reached. The defect was then filled with porous hydroxyapatite granules [Ca10(PO4)6(OH)2] (GenPhos HA-TCP, Genius, Baumer S.A.) (Fig. 2). The skin and musculature were repositioned and closed with 5-0 suture. The animals were sacrificed 2 months after bone defect creation with an overdose of the anesthetic, followed by $\mathrm{CO} 2$ inhalation. The left tibiae were removed for morphological analysis of bone healing in the wound area.

Radiologic and Histologic Analysis. The samples were radiographed with a Rigaku RU-200 apparatus using a focal spot size of $0.8 \times 0.8 \mathrm{~mm}$ and Kodak films $(7.6 \times 5.7 \mathrm{~cm})$. Next, the samples were submitted to routine histological processing and semi-serial $5-\mu \mathrm{m}$ cross-sections were cut and stained with hematoxylin-eosin. 


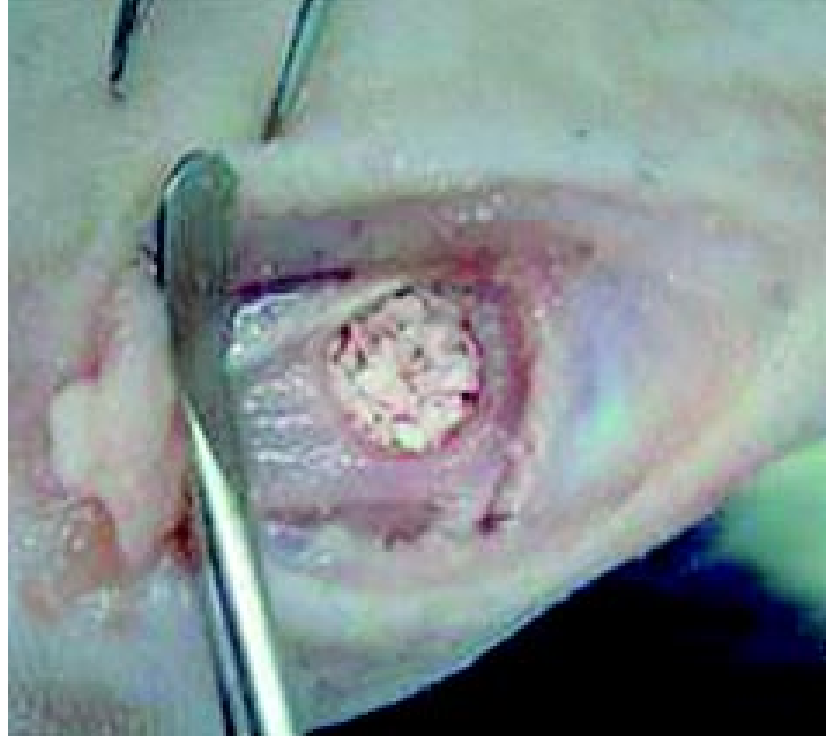

Fig. 2. Surgery for creating the defect in the tibia and filling with hydroxyapatite.

\section{Stereological and Statistical Analysis of the Volume of Newly Formed Bone in the Wound Area. Newly formed bone at the implant site was quantified using the following formula: $\mathrm{Vv}=\mathrm{Pp} / \mathrm{Pt}(\%)$, where $\mathrm{Vv}$ is the volume density or relative density; $\mathrm{Pp}$ is the number of points (line intersection) on newly formed bone, and $\mathrm{Pt}$ is the total number of points of the system (Mandarim-de-Lacerda, 1999). The volume of newly formed bone in the defect area was compared between groups by Anova followed by the Tukey test, with $\mathrm{p}<0.05$ indicating a significant difference.}

\section{RESULTS}

Radiologic Analysis. The hydroxyapatite granules were condensed and exhibited good radiopacity. No absorption or migration to distant areas was observed. Radiolucent spaces were noted at some points along the defect margin and between some hydroxyapatite granules, and were suggestive of connective tissue infiltration. However, there were no radiologic signs of pathological alterations, indicating the biocompatibility of the hydroxyapatite implant (Fig. 3).

Histologic Analysis. In animals of G1 and G2, new bone formation was observed adjacent to the hydroxyapatite granules, particularly those located deep in the bone defect and near the medullar canal. The formation of new bone was more intense in $\mathrm{G} 1$ as demonstrated by the observation that some granules were completely encapsulated by new bone. Considerable proliferation of connective tissue in the bone defect area was observed in G2, especially around hydroxyapatite granules located in the superficial part of the bone defect. New bone was formed from the margins of the bone defect and exhibited characteristics of mature bone in some areas, including the presence of organized osteocytes. However, a trabecular arrangement of the young immature bone was noted in some areas, with the formation of cavities filled with hematopoietic tissue. No pathological alterations such as inflammatory processes, cysts or other signs characteristic of immune rejection were observed (Fig. 4).

Stereology Analysis. The relative volume $(\% \pm$ standard deviation) of new bone in the defect area was $23.5 \pm 1.290$ in G1 and $12.75 \pm 1.707$ in $\mathrm{G} 2$, with the difference being significant $(\mathrm{p}<0.05)$ (Fig. 5).

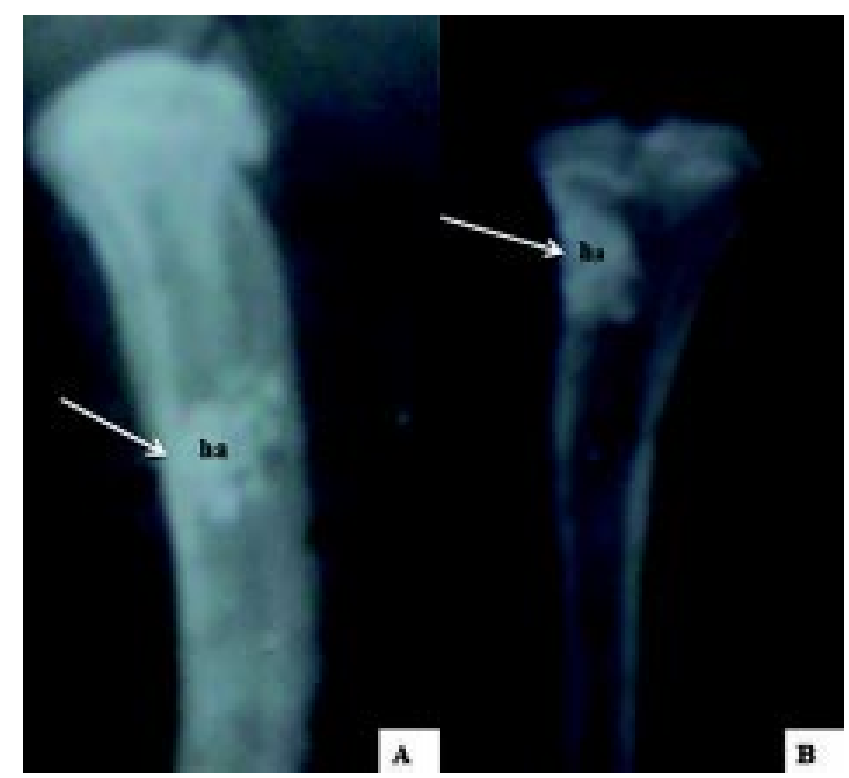

Fig. 3. Radiologic images. Note concentration of radiopacity of the hydroxyapatite granules (ha).

\section{DISCUSSION}

In the present study, changes in bone metabolism were induced in the animals by section of the left sciatic nerve near its origin in the lumbar spine, causing paralysis of the corresponding hind limb. Four months after this procedure, the time interval expected for the occurrence of tibial bone alterations, the animals were submitted to another surgery for creation of a bone defect in the left tibia which was filled with porous hydroxyapatite granules. The objective was to evaluate the osteogenic process at the implant site in response to abnormal bone homeostasis induced by disuse due to sectioning of the sciatic nerve. 


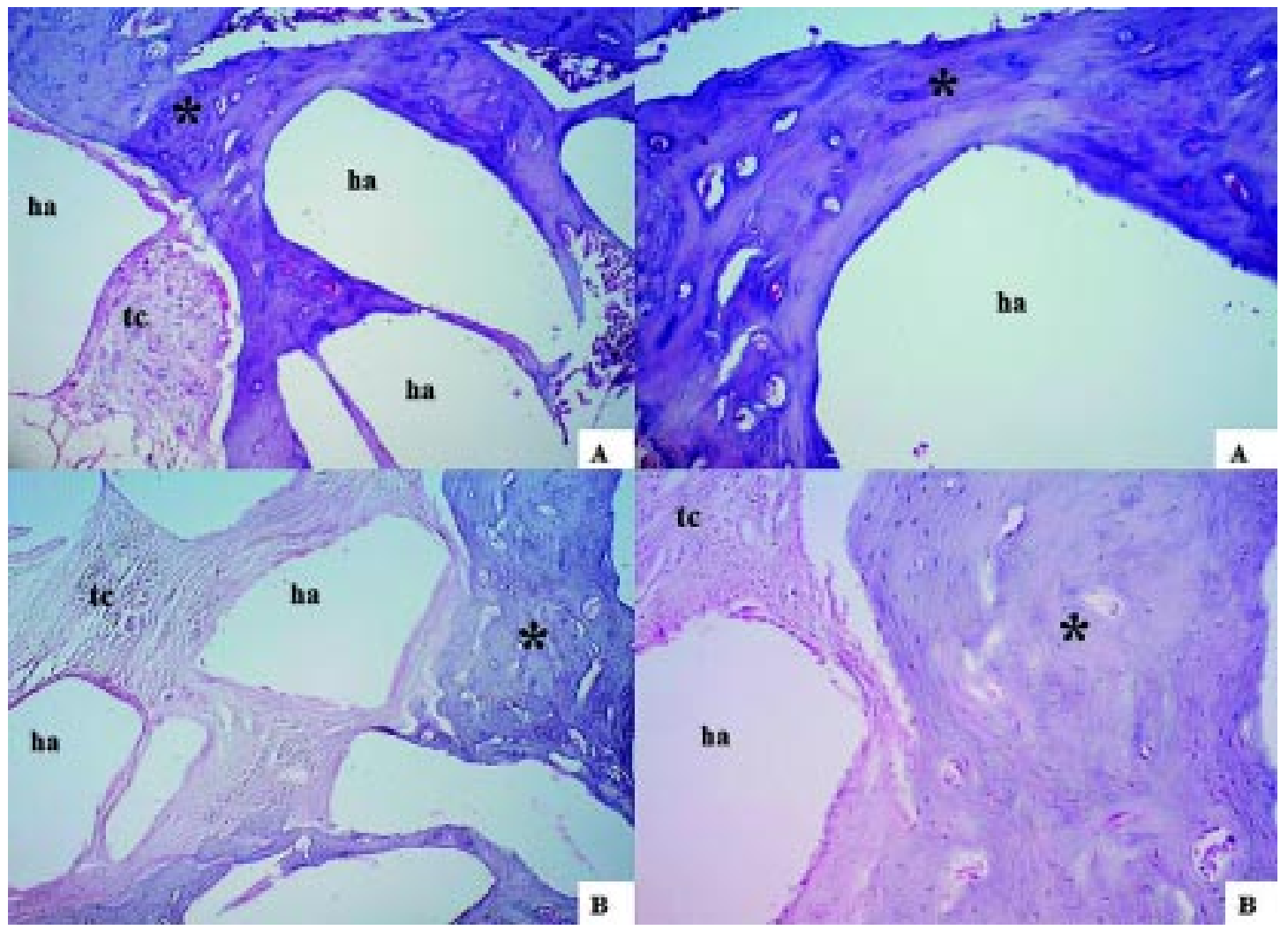

Fig. 4. Morphologic analyses of area bone wound of groups G1 and G2. Note the new bone formation (*) adjacent to hydroxyapatite granules (ha) in G1 (A). In G2 observed abundant connective tissue (tc) (B).

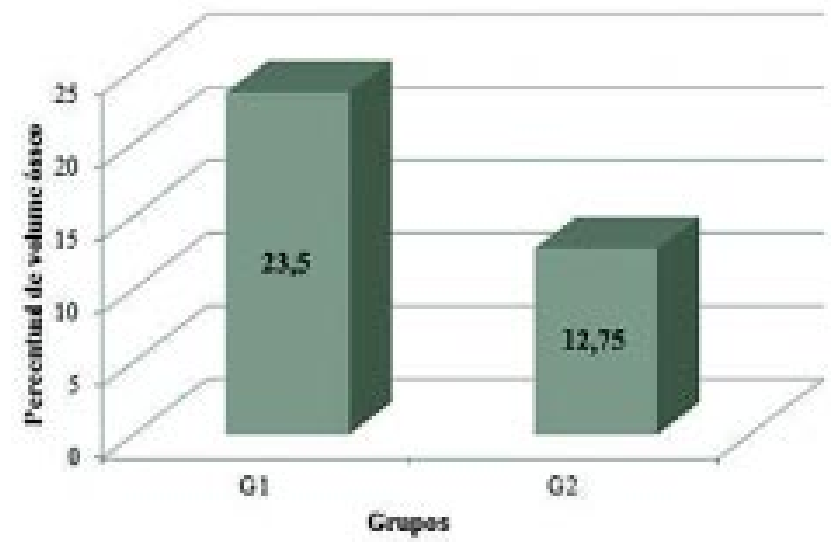

Fig. 5. Stereology analysis demonstrating the percentage of newly formed bone.

The results of macroscopic analysis showed no difference in body weight between animals with and without sciatic nerve injury, suggesting that skeletal unloading due to muscle inactivity of the hind limbs did not contribute to the loss of bone integrity demonstrated by histologic analysis. Similar results have been reported by Offley et al. (2005) who evaluated the contribution of capsaicinsensitive sensory neurons to the maintenance of trabecular bone integrity. These authors also observed a loss of bone mineral density in the tibial and femoral metaphyses of rats 4 weeks after capsaicin treatment. In the proximal tibia, the number of osteoclasts increased on the surface, osteoblast activity and bone formation were impaired, and the trabecular bone volume and connectivity were reduced. There was also a loss of bone strength in the distal femur. Thus, neuronal damage seems to alter bone homeostasis, causing bone resorption, reducing new bone formation and bone mass, inducing the loss of trabecular bone integrity and bone strength, and increasing bone fragility. These results support the hypothesis that sensory neurons contribute to the maintenance of trabecular bone integrity, which can be explained by the fact that neuropeptides such as substance $P$ and calcitonin gene-related peptide (CGRP) are synthesized by sensory neurons and released from peripheral nerve terminals. A reduction in the levels of these local neuropeptides in bone affects bone integrity (Maayan et al. 2001; Offley et al.).

Neuronal damage reduces the levels of substance $\mathrm{P}$ and CGRP, neuropeptides involved in bone metabolism. Bone loss occurs as a consequence of the reduction in trabecular connectivity and cortical thickening, causing bone 
fragility. Studies have shown the rapid loss of trabecular bone in the hind limbs of rats after unilateral sciatic nerve transection, which was exacerbated by the chronic administration of an antagonist of the substance $\mathrm{P}$ receptor NK1 (Kingery et al., 2003). This experiment suggests that the inhibition of substance P signaling may exert deleterious effects on bone mass. Other studies also demonstrated the regulation of bone metabolism by substance P and CGRP, since nerve fibers containing these neuropeptides enter the bone with blood vessels and terminate in the bone marrow, exerting their bone homeostatic function. Immunocytochemical studies have shown the presence of the substance $\mathrm{P}$ receptor (NK1) on the plasma membrane and in the cytoplasm of osteoclasts, osteoblasts and osteocytes, and NK1 mRNA expression has been demonstrated in osteoclasts. Furthermore, substance P can increase osteoblastogenesis, inducing bone formation and protein accumulation in bone cell cultures (Bjurholm et al., 1992; Shih \& Bernard, 1997; Goto et al., 1998; Adamus \& Dabrowski, 2001; Offley et al.; Togari, 2002). In contrast, CGRP inhibits bone resorption in vitro (Imai \& Matsusue, 2002), and increases cyclic AMP (Bjurholm et al.) and intracellular calcium in osteoblasts (Kawase et al., 1995).

Other studies also showed that nerve injury predisposes to the occurrence of osteoporosis as a result of alterations in bone mineral metabolism caused by disuse due to paralysis. The consequences are a reduction in the mechanical stress on bones, a reduced stimulus for bone neoformation by osteoblasts, and a disproportional increase in bone resorption by osteoclasts, which render bone more fragile and predispose to fractures that require natural or synthetic grafts (Garland et al., 1992).
Since bone mineral density is the result of a dynamic process of bone remodeling characterized by a balance between bone formation and resorption and the latter depends on muscle use, the healing of a bone defect can be compromised in cases of paralysis due to nerve injury (Creighton et al., 2001). Corroborating this observation, in the present study stereology showed a marked and significant reduction in the volume of newly formed bone in the wound areas of animals with sciatic nerve section, which was almost half the bone volume observed in animals with intact sciatic nerves. Furthermore, considerable proliferation of connective tissue adjacent to the hydroxyapatite granules was observed in animals with sciatic nerve section, compromising the osseointegration of this bioceramic and, consequently, bone healing.

\section{CONCLUSION}

No adequate formation of new bone and osseointegration of the hydroxyapatite implants was observed in animals with sciatic nerve injury. These findings suggest that the abnormal health conditions of bone tissue with altered metabolism due to the lack of neuromuscular stimulation resulting from peripheral nerve injury may interfere with the velocity of bone neoformation during natural bone regeneration in cases of traumas or congenital defects accompanied by bone loss.

ACKNOWLEDGMENTS. Financial support PIBIC/CNPq and NAPED/FMJ.

DA CUNHA, M. R.; LARAIA, I. O.; FRANCO, G. R.; MIGUEL, N. N.; MACIEL, A. A.; DOS SANTOS, G. R. \& ISAYAMA, R. N. Oseointegración de implantes de hidroxiapatita en defectos tibiales de ratas con lesión del nervio ciático. Int. J. Morphol., 33(2):620$625,2015$.

RESUMEN: El metabolismo óseo está influenciado por diferentes factores y la actividad muscular como un estimulador de la plasticidad ósea. Condiciones tales como lesiones nerviosas pueden comprometer la fisiología ósea debido a la inactividad muscular. Estudios previos han demostrado que el daño nervioso reduce la sustancia $\mathrm{P}$ y el péptido relacionado con el gen de la calcitonina, también conocidos como neuropéptidos que pueden tener un papel clave en la cicatrización ósea. Este estudio evaluó la oseointegración de los implantes de hidroxiapatita en defectos tibiales de ratas sometidas a la sección del nervio ciático unilateralmente. Doce ratas Wistar se dividieron en dos grupos (G1 y G2). En G1, el nervio ciático se dejó intacto y en el G2 el nervio ciático izquierdo fue completamente seccionado. Un defecto óseo tibial fue creado experimentalmente en ambos grupos y se rellenó con gránulos de hidroxiapatita. Los animales se sacrificaron 2 meses después de la implantación y las muestras fueron sometidas a inspección macroscópica y el análisis histológico. Se observó buena radiopacidad de los gránulos de hidroxiapatita y definición radiográfica del defecto óseo. El análisis histológico reveló neoformación ósea adyacente a los gránulos de hidroxiapatita en G1 y, en menor medida en G2, donde la proliferación de tejido conectivo predominó en el sitio de implante. La neoformación ósea estimulada por hidroxiapatita en defectos óseos se puede esperar incluso en animales con parálisis de los miembros producto de una lesión nerviosa; sin embargo, la formación de hueso se produce a menor velocidad en estos animales y su volumen es menor.

PALABRAS CLAVE: Hidroxiapatita; Nervio ciático; Consolidación ósea. 


\section{REFERENCES}

Adamus, M. A. \& Dabrowski, Z. J. Effect of the neuropeptide substance $\mathrm{P}$ on the rat bone marrow-derived osteogenic cells in vitro. J. Cell Biochem., 81(3):499-506, 2001.

Babiker, H. Bone graft materials in fixation of orthopaedic implants in sheep. Dan. Med J., 60(7):B4680, 2013.

Biering-Sorensen, F.; Bohr, H. \& Schaadt, O. Bone mineral content of the lumbar spine and lower extremities years after spinal cord lesion. Paraplegia, 26(5):293-301, 1988.

Bjurholm, A.; Kreicbergs, A.; Schultzberg, M. \& Lerner, U. H. Neuroendocrine regulation of cyclic AMP formation in osteoblastic cell lines (UMR-106-01, ROS 17/2.8, MC3T3-E1, and Saos-2) and primary bone cells. J. Bone Miner. Res., 7(9):1011-9, 1992.

Brito, C. M. M.; Battistella, L. R.; Sakamoto, H. \& Saito, E. T. Bone mineral status after spinal cord injury. Acta Fisiatr., 9(3):127-33, 2002.

Creighton, D. L.; Morgan, A. L.; Boardlev, D. \& Brolinson, P. G. Weight-bearing exercise and markers of bone turnover in female athletes. J. Appl. Physiol. (1985), 90(2):565-70, 2001.

da Cunha, M. R.; Gushiken, V. O.; Mardegan Issa, J. P.; Iatecola, A.; Pettian, M. \& Santos, A. R. Jr. Osteoconductive capacity of hydroxyapatite implanted into the skull of diabetics. J. Craniofac. Surg., 22(6):2048-52, 2011.

Demulder, A.; Guns, M.; Ismail, A.; Wilmet, E.; Fondu, P. \& Bergmann, P. Increased osteoclast-like cells formation in long-term bone marrow cultures from patients with a spinal cord injury. Calcif. Tissue Int., 63(5):396-400, 1998.

Franco, G. R.; Laraia, I. O.; Maciel, A. A.; Miguel, N. M.; Dos Santos, G. R.; Fabrega-Carvalho, C. A.; Pinto, C. A.; Pettian, M. S. \& Cunha, M. R. Effects of chronic passive smoking on the regeneration of rat femoral defects filled with hydroxyapatite and stimulated by laser therapy. Injury, 44(7):908-13, 2013.

Garland, D. E.; Stewart, C. A.; Adkins, R. H.; Hu, S. S.; Rosen, C.; Liotta, F. J. \& Weinstein, D. A. Osteoporosis after spinal cord injury. J. Orthop. Res., 10(3):371-8, 1992.

Goto, T.; Yamaza, T.; Kido, M. A. \& Tanaka, T. Light- and electronmicroscopic study of the distribution of axons containing substance $P$ and the localization of neurokinin-1 receptor in bone. Cell Tissue Res., 293(1):87-93, 1998.

Hönig, J. F.; Merten, H. A. \& Wiltfang, J. Significance of the periosteum in onlay craniofacial augmentation. J. Craniofac. Surg., 9(3):2606, 1998 .

Imai, S. \& Matsusue, Y. Neuronal regulation of bone metabolism and anabolism: calcitonin gene-related peptide-, substance $\mathrm{P}$, and tyrosine hydroxylase-containing nerves and the bone. Microsc. Res. Tech., 58(2):61-9, 2002.

Kawase, T.; Howard, G. A.; Roos, B. A. \& Burns, D. M. Diverse actions of calcitonin gene-related peptide on intracellular free $\mathrm{Ca} 2+$ concentrations in UMR 106 osteoblastic cells. Bone, $16(4$ Suppl.):379S-84S, 1995.

Kingery, W. S.; Offley, S. C.; Guo, T. Z.; Davies, M. F.; Clark, J. D. \& Jacobs, C. R. A substance P receptor (NK1) antagonist enhances the widespread osteoporotic effects of sciatic nerve section. Bone, 33(6):927-36, 2003.

Kocina, P. Body composition of spinal cord injured adults. Sports Med., 23(1):48-60, 1997.

Lee, T. Q.; Shapiro, T. A. \& Bell, D. M. Biomechanical properties of human tibias in long-term spinal cord injury. J. Rehabil. Res. Dev., 34(3):295-302, 1997.

LeGeros, R. Z. Calcium phosphate-based osteoinductive materials. Chem. Rev., 108(11):4742-53, 2008.

Maayan, C.; Becker, Y.; Gesundheit, B. \& Girgis, S. I. Calcitonin gene related peptide in familial dysautonomia. Neuropeptides, 35(34):189-95, 2001.

Mandarim-de-Lacerda, C. A. What is the interest of normal and pathological morphological research to be quantitative? The example of stereology. Braz. J. Morphol. Sci., 16(2):131-9, 1999.

Offley, S. C.; Guo, T. Z.; Wei, T.; Clark, J. D.; Vogel, H.; Lindsey, D. P.; Jacobs, C. R.; Yao, W.; Lane, N. E. \& Kingery, W. S. Capsaicinsensitive sensory neurons contribute to the maintenance of trabecular bone integrity. J. Bone Miner. Res., 20(2):257-67, 2005.

Shih, C. \& Bernard, G. W. Neurogenic substance P stimulates osteogenesis in vitro. Peptides, 18(2):323-6, 1997.

Sugata, Y.; Sotome, S.; Yuasa, M.; Hirano, M.; Shinomiya, K. \& Okawa, A. Effects of the systemic administration of alendronate on bone formation in a porous hydroxyapatite/collagen composite and resorption by osteoclasts in a bone defect model in rabbits. J. Bone Joint Surg. Br., 93(4):510-6, 2011.

Togari, A. Adrenergic regulation of bone metabolism: possible involvement of sympathetic innervation of osteoblastic and osteoclastic cells. Microsc. Res. Tech., 58(2):77-84, 2002.

Wilmet, E.; Ismail, A. A.; Heilporn, A.; Welraeds, D. \& Bergmann, P. Longitudinal study of the bone mineral content and of soft tissue composition after spinal cord section. Paraplegia, 33(11):674-7, 1995.

\section{Correspondence to:}

Prof. Dr. Marcelo Rodrigues da Cunha

Department of Morphology and Pathology

Faculty of Medicine of Jundiaí

Rua Francisco Telles, 250

Vila Arens, Jundiaí

CEP. 13202-550, Cx. Postal 1295

São Paulo

BRAZIL

Email: cunhamr@hotmail.com

Received: 04-11-2014 Accepted: 09-02-2015 